machine, oxyacetylene welding, turbines, steel tubes, steel wire ropes, etc. The object of the South Wales Institute of Engineers in organising these exhibitions is mainly educational, and all students from the university colleges, the technical colleges, the county council mining schools, and members of all engineering societies and institutions are admitted free to the Exhibition. Another object is, of course, to bring the manufacturer into touch with the consumer, and so help in developing the industries of the district.

\section{Popularity of the Electric Trolley Omnibus}

THE use of the electric trolley omnibus is rapidly increasing. Not only has it replaced electric tramways operating on unremunerative routes, but it has also sometimes replaced petrol buses. It will have to be taken into consideration when new transport schemes arise. In the Metropolitan-Vickers Gazette for November, the application of this method to town and inter-urban transport is discussed. It is stated that at the present time there are 24 installations of this kind in Great Britain, operating over 250 route miles of track. Its operating flexibility lies between that of a tramcar which is confined to its rails and a petrol bus which has complete freedom of movement. The acceleration of a trolley bus is twice that of a motor bus and it has no gear changing jars. Its schedule speed is high, although it does not exceed the maximum speed laid down by the Ministry of Transport. Compared with a tramcar it has the great advantage of being able to draw up to the kerb. This is a great convenience to passengers, and avoids obstructing the traffic. The absence of reciprocating and wearing parts in the electrical equipment results in a low maintenance cost, and very little time is spent in the repair shops. Its life is fifty per cent longer than that of the petrol bus. The most doubtful feature seems to be the cost and upkeep of the overhead equipment. If this cost is very high the motor bus may be the more economical. From the driver's point of view, the light foot-operated controller takes the place of the motor bus accelerator pedal. The absence of gears leaves the driver's hands entirely free for steering. The driving of a trolley bus therefore requires much less skill than driving a motor bus. With this system also, Great Britain is using its national fuel resources and not imported fuel.

\section{Exhibition of Types of Native Boats}

AN exhibition of the main types of native boats, and their distriburion throughout the world, will be opened at the Science Museum, South Kensington, on December 2. The exhibition deals with the boats which are used for transport, and for fishing, in the rivers and along the coasts of the different continents, but is not concerned with the larger ocean-going vessels, or with the steel-built ships of the more civilised races. In any locality the design of a boat and its method of construction depend on the service for which the boat is required, the material available, the racial affinities of the builder, and the contacts of the builder and of his ancestors with other races. As a result of the interaction of these factors, we find very great differences between boats used under apparently similar conditions in neighbouring districts, while we equally find marked similarities between boats built by totally different races and in widely separate parts of the world. Thus punt-shaped boats are commonly used on nearly all the rivers and inland waterways of Europe and over a great part of Asia. Their form is suitable for use on rivers, and long planks, produced either by splitting or by sawing, can be obtained along the banks of these rivers. But it is at least doubtful whether the prevalence of this punt-shaped type indicates any racial affinities between east and west, or even early contacts. Contrary to the usual practice, the exhibits are being arranged in accordance with their forms and types of construction, instead of geographically, and it is hoped that this grouping will serve to bring into prominence differences and similarities which the more usual arrangement has failed to disclose.

\section{Statistical Methods in Industry and Agriculture}

THE first meeting of the newly-formed Industrial and Agricultural Research Section of the Royal Statistical Society was held on November 23, when Dr. R. H. Pickard, director of the British Cotton Industry Research Association, gave an address on. "The Application of Statistical Methods to Production and Research in Industry". Dr. Pickard referred to the important part now being played in the study of the technical problems of industry by the statistical methods initiated by Prof. Karl Pearson forty years ago. He pointed out the similarity between the statistical technique used in problems arising in cotton trade research and that developed by Prof. R. A. Fisher at Rothamsted in agricultural research. $\mathrm{He}$ gave a number of illustrations taken from the work of the British Cotton Industry Research Association showing the wide scope and utility of modern statistical methods applied to the sampling problems occurring in that industry. Discussing the question of the employment of fully-trained statisticians in industry, Dr. Pickard emphasised the need for the statistician to be well-trained in a knowledge of the processes of the industry. It is proposed to hold four meetings each session of the new Section and to publish a supplement to the Society's Journal (published four times a year) which will be devoted to the subject of statistical methods applied to industry and agriculture.

\section{Royal Ontario Museum}

THE Royal Ontario Museum at Toronto was officially reopened on October 12 by the Prime Minister of Ontario in the presence of the Lieutenant Governor and other officials of the Province and of the University of Toronto. The Museum was originally opened in 1914 as a combination university and provincial museum. The interior of the old building has been completely remodelled and a large addition constituting the main section of the building erected at a cost of nearly $2,000,000$ dollars. The front section houses the natural history galleries, including those of geology, mineralogy, palæontology and zoology, and the connecting link, and the old 